\title{
EFFECT OF 2-METHOXYESTRADIOL ON GONADOTROPIN SECRETION AND OXIDATIVE STATUS OF PORCINE PITUITARY CELLS IN VITRO
}

\author{
URSZULA KOSIOR-KORZECKA, PAULINA RADWAŃSKA, AND MARTA WÓJCIK \\ Department of Pathophysiology, Chair of Preclinical Veterinary Sciences, \\ Faculty of Veterinary Medicine, \\ University of Life Sciences in Lublin, 20-033 Lublin, Poland, \\ urszula.korzecka@up.lublin.pl
}

Received: April 5, 2012

Accepted: August 30, 2012

\begin{abstract}
The aim of the study was to investigate the effect of 2-methoxyestradiol (2-ME) on GnRH-induced LH and FSH secretion by porcine pituitary cells in vitro. Moreover, the concentrations of superoxide anion radical $\left(\mathrm{O}_{2}^{-}\right)$, as a possible mediator of 2-ME action, and malonyldialdehyde (MDA), as an oxidative stress indicator, were estimated. Pituitary cells were cultured in McCoy 5A medium with GnRH (positive control), with $\mathrm{GnRH}$ and $3.3 \times 10^{-11}-3.3 \times 10^{-7} \mathrm{M} / \mathrm{L}$ of 2-ME, or with $\mathrm{GnRH}$ and $2.7 \times 10^{-9}$ $2.7 \times 10^{-8} \mathrm{M} / \mathrm{L}$ of $17 \beta$-estradiol. The secretion of gonadotropins, as well as concentrations of superoxide anion and MDA were analysed after 2-72 $\mathrm{h}$ of the experiment. A positive correlation between 2-ME dose and FSH secretion from anterior pituitary cells $(\mathrm{r}=0.72,0.95,0.92,0.90,0.85$, and 0.82 after $2,6,18,24,48$, and $72 \mathrm{~h}$, respectively) was demonstrated. In contrast, a negative correlation between 2-ME concentration and LH secretion was observed ( $\mathrm{r}=-0.82,-0.72,-0.85,-0.89,-0.93$, and -0.79 after 2,6 , 18, 24,48 , and $72 \mathrm{~h}$, respectively). The concentration of $\mathrm{O}_{2}^{-}$was increasing under the influence of the rising doses of 2-ME, whereas the mean level of MDA was not changing significantly.
\end{abstract}

Key words: swine, 2-methoxyestradiol, pituitary cells, FSH, LH.

2-methoxyestradiol (2-ME) is known as a biologically active, endogenous $17 \beta$-estradiol (E-2) metabolite, which is produced by sequential action of CYP450s and catechol-O-methyltransferase in porcine granulosa cells. 2-ME is released into follicular fluid and, to a lesser extent, into blood (21). Its level is augmented during the growth of follicle. There are a lot of reports showing that 2-ME can be used in experimental treatment of some types of cancer, e.g. angiosarcoma, gastric cancer, hepatocellular carcinoma, neuroblastoma, osteosarcoma, breast cancer, lung cancer, pancreatic cancer, and oestrogen-induced pituitary tumour $(1,20)$, or cardiovascular and renal disorders. According to Ricker et al. (18), 2-ME is a potent inhibitor of tumourigenesis. A crucial role in 2ME-induced antitumour mechanism is played by the inhibition of angiogenesis caused by a decrease in vascular endothelial growth factor (VEGF) synthesis (2, $4)$, as well as antiproliferative and proapoptotic action, which is independent of $\alpha$ and $\beta$ oestrogen receptors (13, 17). Several molecular mechanisms are involved in the process of proliferation inhibition and apoptosis, including microtubule disruption, p53 activation, upregulation of death receptor 5, inhibition of mitochondrial respiration, and the reduction of the superoxide dismutase activity $(9,15,16)$. The cardioprotective effect of 2-ME, instead, is caused by inhibition of vascular smooth muscle cell growth in arteries (22), as well as by reduction of serum cholesterol level and LDL oxidation (6). It was also reported that 2-ME induces vasodilatation by stimulation of NO synthase in artery endothelial cells, NO release, and inhibition of phenylephrine production (8).

Taking into account that 2-ME is E-2 metabolite, its use in cancer treatment, cardiovascular or renal diseases may cause the disorders in GnRH-induced gonadotropin secretion as a side effect. Accordingly, the aim of our study was to investigate the effect of 2-ME on LH and FSH secretion from porcine pituitary cells in vitro. Moreover, the concentrations of superoxide anion radical $\left(\mathrm{O}_{2}^{-}\right)$, as a possible mediator of 2-ME action, and malonyldialdehyde (MDA), as an oxidative stress indicator, were analysed.

\section{Material and Methods}

The pituitary glands were obtained at slaughter from 4-5- year-old sows (Polish Large White breed) with active healthy ovaries during the follicular phase of the oestrous cycle. Isolation of cells was carried out 
through the digestion of the pituitary with $0.25 \%$ trypsin solution. Suspension of cells in trypsin combined with the preparatory medium (DMEM supplemented with $0.1 \%$ BSA, $0.08 \%$ glucose, $0.59 \%$ HEPES, and gentamycin in the final concentration of $20 \mu \mathrm{g} / \mathrm{mL}$ ) was centrifuged (1,200 rpm for $10 \mathrm{~min}$.). The sedimented cells were washed twice and finally cultured in McCoy $5 \mathrm{~A}$ medium containing $2.5 \%$ foetal calf serum, $10 \%$ horse serum, mixture of amino acids and vitamins, 0.59 $\%$ HEPES, gentamycin $(20 \mu \mathrm{g} / \mathrm{mL})$, and adjusted to $\mathrm{pH}$ $7.4(5,11,12)$. One millilitre of dispersed cell suspension $\left(5 \times 10^{5}\right.$ cells $\left./ \mathrm{mL}\right)$ was transferred to each well of the 24-well culture plate and incubated for $96 \mathrm{~h}$ at $37^{\circ} \mathrm{C}$ under the atmosphere of $5 \% \mathrm{CO}_{2}$. After attachment to the dishes, the cells were washed and finally incubated with McCoy 5A medium without hormones (negative control), with $\mathrm{GnRH}\left(4 \times 10^{-9} \mathrm{M} / \mathrm{L}\right)$ (positive control), with GnRH $\left(4 \times 10^{-9} \mathrm{M} / \mathrm{L}\right)$ and $10^{-11}, 10^{-10}, 10^{-9}$, $10^{-8}$, or $10^{-7} \mathrm{M} / \mathrm{L}$ of $2-\mathrm{ME}$ (Sigma Chemical Co., USA), respectively, and with $\mathrm{GnRH}\left(4 \times 10^{-9} \mathrm{M} / \mathrm{L}\right)$ and $10^{-9}$ or $10^{-}$ ${ }^{8} \mathrm{M} / \mathrm{L}$ of E-2 (Sigma Chemical Co., USA), respectively. Each sample was performed in duplicate.

After 2, 6, 18, 24, 48, and $72 \mathrm{~h}$ of incubation, the media were collected for analysis of LH, FSH, superoxide anion radical $\left(\mathrm{O}_{2}{ }^{-}\right)$and MDA concentrations. In parallel, proliferation index (PI) of cells treated with 2-ME and E-2 was determined. The results were used for calculation of LH and FSH secretion. Assessment of cell proliferation was based on the reduction of the tetrazolium salt (MTT) into a blue formazan. Both control and experimental cultures were pulsed with 15 $\mu \mathrm{l}$ of MTT (for $3 \mathrm{~h}$ at $37^{\circ} \mathrm{C}$ ) and then solubilised with SDS overnight. The optical density (OD) of the formed blue formazan was measured by ELISA microplate reader at the wavelength of $600 \mathrm{~nm}$. LH concentration in culture medium was determined using LH $\left[{ }^{125} \mathrm{I}\right]$ IRMA KIT (Orion Diagnostica, Spectria, Finland), whereas FSH level using FSH ${ }^{125}$ I] IRMA KIT (Orion Diagnostica, Spectria, Finland). Gonadotropin secretion was expressed as a concentration (IU/L) of given hormone (LH or FSH), which was released into the culture medium by $5 \times 10^{5}$ cells during $2,6,18,24,48$, and $72 \mathrm{~h}$, respectively.

Medium concentration of MDA was measured spectrophotometrically. Samples of $0.25 \mathrm{ml}$ medium were mixed with $1.25 \mathrm{ml}$ of trichlororacetic acid (TCA) and $0.75 \mathrm{ml}$ of thiobarbituric acid and thereafter heated for $20 \mathrm{~min}$ in a boiling water bath. After cooling of the sample to the room temperature, $2 \mathrm{ml}$ of $\mathrm{n}$-butanol was added and the mixture was shaken vigorously for $3 \mathrm{~min}$, and centrifuged $10 \mathrm{~min}$ at $1,500 \mathrm{x}$ g. After the transfer of upper n-butanol layer to the glass cuvette, its absorbance was measured at $532 \mathrm{~nm}$. Concentrations of MDA were calculated on the basis of the standard curve obtained using malondialdehyde bis-dimethylacetal.

Superoxide anion radical was measured by Confer method. The collected medium was immediately mixed with $0.1 \%$ nitroblue tetrazolium (NBT, Sigma) solution and incubated at room temperature for $10 \mathrm{~min}$. Thereafter, absorbance was read at $545 \mathrm{~nm}$. Nanomoles of superoxide anion radical produced over the incubation period were calculated using the extinction coefficient $21.1 \mathrm{nmol}$.

The obtained results were calculated using Statistica 5.0 PL and expressed as a mean and standard deviation $(x \pm \mathrm{SD})$. Comparisons between the control and experimental cultures were performed using analysis of variance and the paired $t$-tests. Differences were considered as significant at $\mathrm{P} \leq 0.05$ or $\mathrm{P} \leq 0.001$.

\section{Results}

The effect of 2-methoxyestradiol on FSH secretion from porcine pituitary cells. The average secretion of FSH amounted to $8.72 \pm 2.67 \mathrm{IU} / \mathrm{L} / 5 \times 10^{5}$ cells during the whole time of the experiment $(0-72 \mathrm{~h})$ in the negative control culture, whereas in the positive control it was $16.75 \pm 4.76 \mathrm{IU} / \mathrm{L} / 5 \times 10^{5}$ cells. The addition of $10^{-11}-10^{-9} \mathrm{M} / \mathrm{L}$ of $2-\mathrm{ME}$ to culture medium did not affect FSH secretion significantly in comparison to the positive control. Treatment of the cells with $10^{-8}$ and $10^{-7} \mathrm{M} / \mathrm{L}$ of $2-\mathrm{ME}$ resulted in a significant $(\mathrm{P} \leq 0.05)$ increase in FSH secretion starting from $48 \mathrm{~h}$ or $6 \mathrm{~h}$ of exposition, respectively. After $72 \mathrm{~h}, \mathrm{FSH}$ secretion under the influence of $10^{-8}$ and $10^{-7} \mathrm{M} / \mathrm{L}$ of $2-\mathrm{ME}$ reached the maximum values $(31.81 \pm 2.31$ and 34.47 $\pm 1.95 \mathrm{IU} / \mathrm{L} / 5 \times 10^{5}$ cells $/ 72 \mathrm{~h}$, respectively). It was significantly $(\mathrm{P} \leq 0.001)$ higher compared to positive control (23.64 $\pm 1.36 \quad \mathrm{IU} / \mathrm{L} / 5 \times 10^{5} \quad$ cells $\left./ 72 \mathrm{~h}\right)$. Comparison of the effect of the same doses of 2-ME and E-2 $\left(10^{-9}\right.$ and $\left.10^{-8} \mathrm{M} / \mathrm{L}\right)$ showed the significantly $(\mathrm{P} \leq 0.001)$ lower stimulation of FSH secretion under the influence of $2-\mathrm{ME}$ than E-2 $\left(42.57 \pm 2.45 \mathrm{IU} / \mathrm{L} / 5 \times 10^{5}\right.$ cells $/ 72 \mathrm{~h}$ and $44.25 \pm 3.55 \mathrm{IU} / \mathrm{L} / 5 \times 10^{5}$ cells/72 $\mathrm{h}$, respectively) (Fig. 1A). The positive correlation between 2-ME concentration in culture medium and FSH secretion from anterior pituitary cells $(\mathrm{r}=0.72, \mathrm{r}=0.95$, $\mathrm{r}=0.92, \mathrm{r}=0.90, \mathrm{r}=0.85$, and $\mathrm{r}=0.82$ after $2,6,18,24,48$, and $72 \mathrm{~h}$, respectively) was found (Fig. 2A).

The effect of 2-methoxyestradiol on LH secretion from porcine pituitary cells. The average secretion of $\mathrm{LH}$ amounted to $54.03 \pm 28.86 \mathrm{IU} / \mathrm{L} / 5 \times 10^{5}$ cells during the whole time of the experiment $(0-72 \mathrm{~h})$ in the negative control culture, whereas in the positive control it was $91.55 \pm 39.92 \mathrm{IU} / \mathrm{L} / 5 \times 10^{5}$ cells. The influence of 2-ME on $\mathrm{LH}$ secretion depended on time and dose of 2-ME used. The introduction of 2-ME in concentration of $10^{-11}, 10^{-10}, 10^{-9}$, and $10^{-8} \mathrm{M} / \mathrm{L}$ did not affect significantly LH secretion in comparison to the positive control; however, it was subtly increased in cell cultures treated with abovementioned doses of 2-ME after 2, 6, 18, and $24 \mathrm{~h}$. After $72 \mathrm{~h}$, LH secretion was insignificantly decreased under the influence of $10^{-9}$ and $10^{-8} \mathrm{M} / \mathrm{L}$ concentrations (Fig. 1B). The highest concentration of $2-\mathrm{ME}\left(10^{-7} \mathrm{M} / \mathrm{L}\right)$ significantly $(\mathrm{P} \leq 0.05)$ reduced LH secretion from porcine pituitary cells starting from $18 \mathrm{~h}$ of the experiment. Comparison of the effect of the same doses of 2-ME and E-2 $\left(10^{-9}\right.$ and $10^{-8}$ $\mathrm{M} / \mathrm{l}$ ) showed the significantly lower stimulation of $\mathrm{LH}$ secretion under the influence of 2-ME than E-2 after 2, 6,18 , and $24 \mathrm{~h}$. After $72 \mathrm{~h}$, instead, an opposite effect of 
$10^{-9}$ and $10^{-8} \mathrm{M} / \mathrm{L}$ of $2-\mathrm{ME}$ and $\mathrm{E}-2$ on LH secretion was observed (Fig. 1B). The negative correlation between 2ME dose and LH secretion from anterior pituitary cells $(\mathrm{r}=-0.82, \mathrm{r}=-0.72, \mathrm{r}=-0.85, \mathrm{r}=-0.89, \mathrm{r}=-0.93$, and $\mathrm{r}=$ 0.79 after $2,6,18,24,48$, and $72 \mathrm{~h}$, respectively) was found (Fig. 2B).

Influence of 2-ME on superoxide anion radical and MDA concentration in the culture medium. A

A.

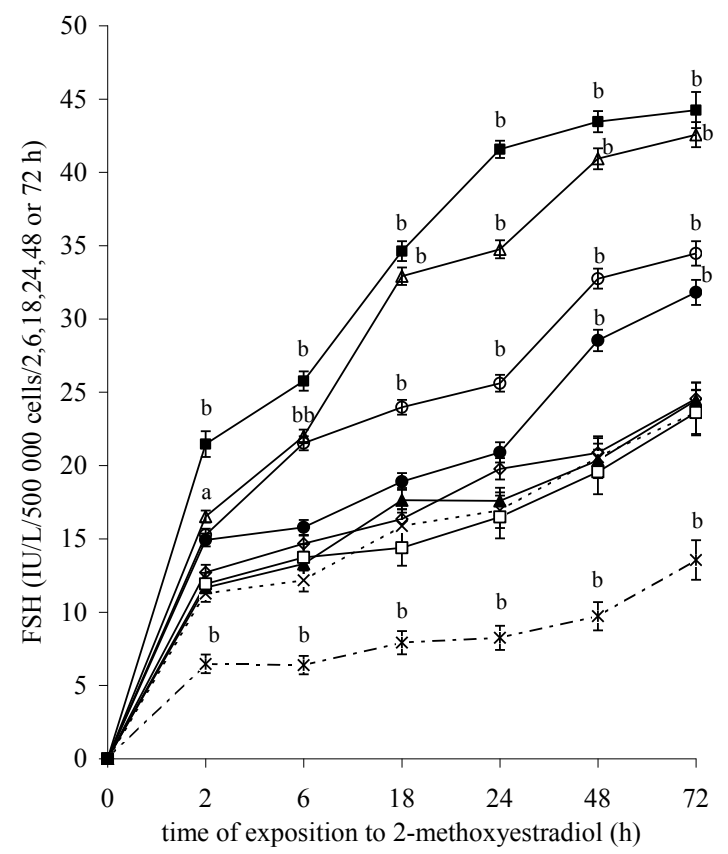

B.

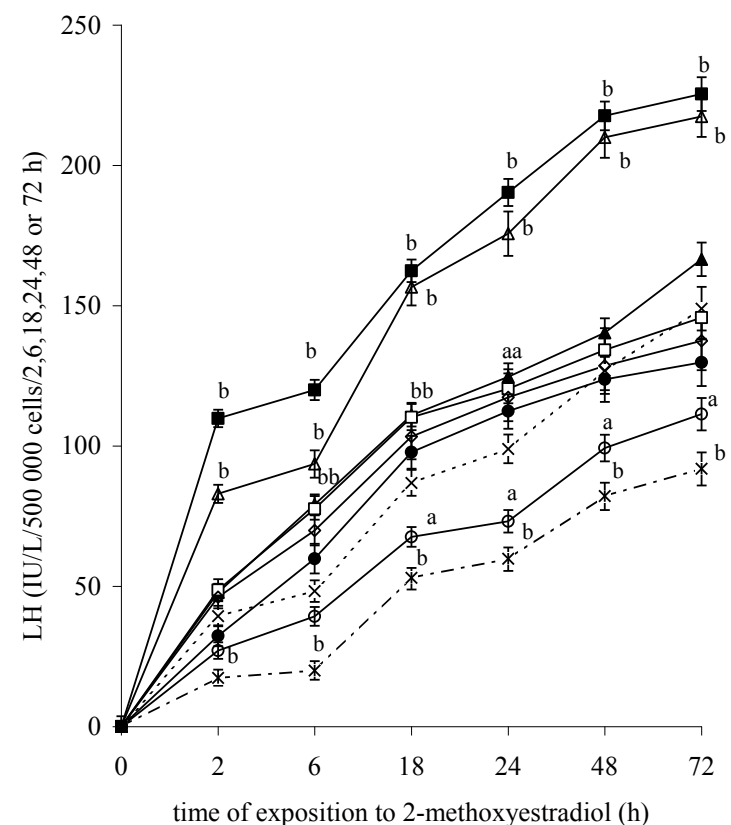

positive linear correlation between 2-ME and mean superoxide anion radical concentration was found $(\mathrm{r}=0.72)$ (Fig. 3). The concurrent analysis of relationship between 2-ME and mean MDA concentration during the experiment $(0-72 \mathrm{~h})$ showed a negative correlation $(\mathrm{r}=-$ 0.45). However, the mean level of MDA was not changing in a significant way (Table 1).

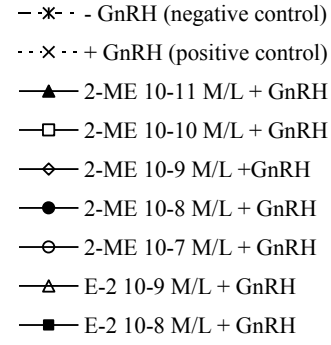

--*- - negative control (-GnRH)

-. - $\times$ - positive control $(+\mathrm{GnRH})$

$\smile$ 2-ME $10-11 \mathrm{M} / \mathrm{L}+\mathrm{GnRH}$

$\longrightarrow$-2-ME 10-10 M/L + GnRH

$\multimap$ 2-ME 10-9 M/L+ GnRH

$\longrightarrow 2-\mathrm{ME}$ 10-8 M/L + GnRH

-2-ME 10-7M/L + GnRH

$\triangle$ E-2 10-9 M/L + GnRH

- $\mathrm{E}-2$ 10-8 M/L $+\mathrm{GnRH}$

Fig. 1. The effect of 2-methoxyestradiol on FSH (A) and LH (B) secretion from porcine pituitary cells in vitro $(\mathrm{a}, \mathrm{b}-$ significant difference in comparison to positive control $(\mathrm{P} \leq 0.05$ or $\mathrm{P} \leq 0.001$, respectively)). 
A.

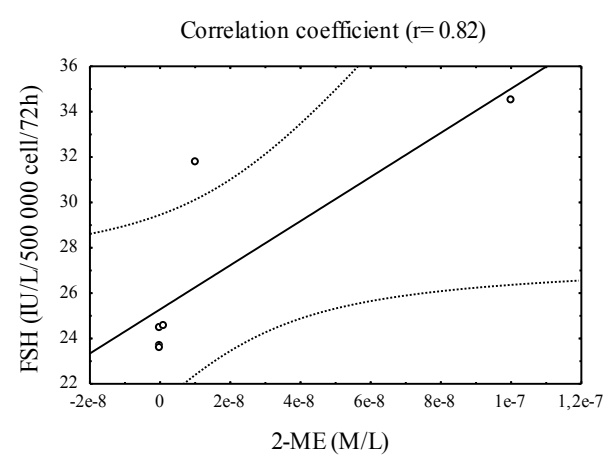

B.

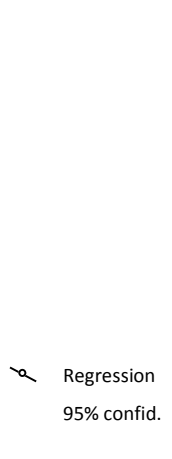

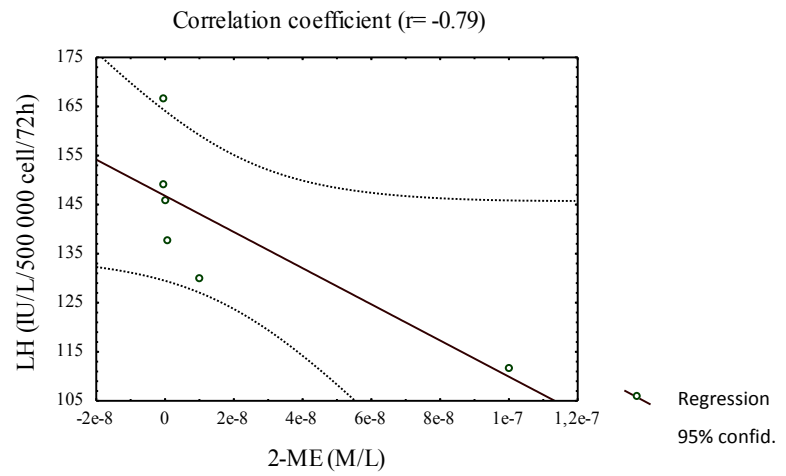

Fig. 2. Relationship between 2-methoxyestradiol (2-ME) and FSH (A) or LH (B) secretion from porcine pituitary cells in vitro after $72 \mathrm{~h}$ of incubation.

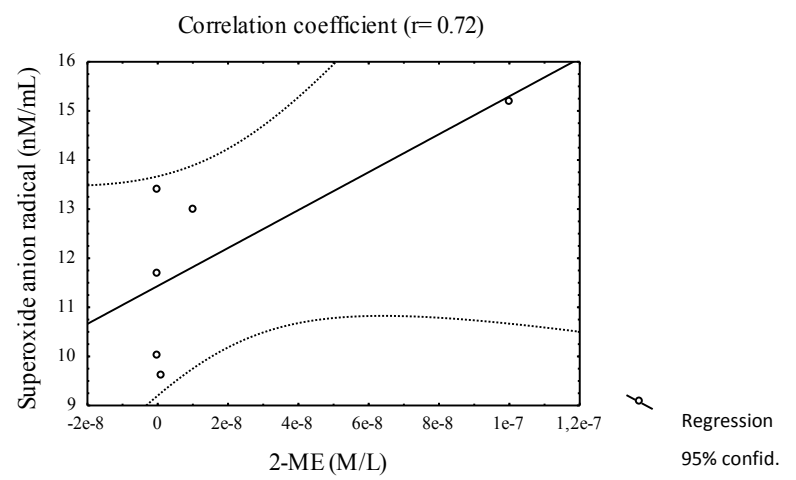

Fig. 3. Relationship between 2-methoxyestradiol (2-ME) (M/L) and concentration of superoxide anion radical (nM/mL) produced by porcine pituitary cells in vitro.

Table 1

Effect of 2-ME on mean MDA concentration $(x \pm S D)$ in culture medium

\begin{tabular}{cccccccccc}
\hline & $\begin{array}{c}\text { Negative } \\
\text { control }\end{array}$ & $\begin{array}{c}\text { Positive } \\
\text { control }\end{array}$ & $\begin{array}{c}2-\mathrm{ME} \\
\left(10^{-11} \mathrm{M} / \mathrm{L}\right)\end{array}$ & $\begin{array}{c}2-\mathrm{ME} \\
\left(10^{-10} \mathrm{M} / \mathrm{L}\right)\end{array}$ & $\begin{array}{c}2-\mathrm{ME} \\
\left(10^{-9} \mathrm{M} / \mathrm{L}\right)\end{array}$ & $\begin{array}{c}2-\mathrm{ME} \\
\left(10^{-8} \mathrm{M} / \mathrm{L}\right)\end{array}$ & $\begin{array}{c}2-\mathrm{ME} \\
\left(10^{-7} \mathrm{M} / \mathrm{L}\right)\end{array}$ & $\begin{array}{c}\mathrm{E}-2 \\
\left(10^{-9} \mathrm{M} / \mathrm{L}\right)\end{array}$ & $\begin{array}{c}\mathrm{E}-2 \\
\left(10^{-8} \mathrm{M} / \mathrm{L}\right)\end{array}$ \\
\hline $\mathrm{MDA}$ & 0.55 & 0.60 & 0.60 & 0.55 & 0.70 & 0.65 & 0.55 & 0.55 & 0.55 \\
{$[\mathrm{nM} / \mathrm{mL}]$} & \pm 0.12 & \pm 0.25 & \pm 0.19 & \pm 0.20 & \pm 0.26 & \pm 0.26 & \pm 0.07 & \pm 0.07 & \pm 0.14 \\
& & & & & & & & & \\
\hline
\end{tabular}

\section{Discussion}

The use of 2-methoxyestradiol is suggested in the treatment of many types of cancer or cardiovascular and renal diseases $(1,2,6,16-18,20,22)$. Apart from its widely described auto- and paracrine effect on granulosa, theca, or oocyte cells, it can act also in an endocrine fashion on the pituitary, changing gonadotropin secretion, as a side effect. The obtained results showed that 2-ME affects secretion of gonadotropins from porcine pituitary cells in vitro in a concentration-dependent way. Increasing dose of 2-ME caused enhancement in FSH secretion, but compared to the E-2 this effect was less marked. Positive correlation between 2-ME and FSH confirmed the stimulating effect 2-ME on FSH secretion from pituitary cells. In contrast to FSH, correlation between secretion of LH and dose of 2-ME was negative. It was also observed that 2-ME at relatively low concentration stimulated pituitary cells to secretion of luteinising hormone, while addition of $10^{-}$ ${ }^{7}$ of $2-\mathrm{ME}$ resulted in a decrease in LH secretion. The exact mechanism of action of 2-ME is still unclear. However, the observed relationships could be connected with dual action of 2-ME, which was dependent on its concentration. It was noted that 2-ME at low concentration had a mitogenic influence on ER-positive (oestrogen receptor positive) cells, which was related to 2-ME's residual oestrogen activity, whereas high 
concentration of 2-ME exhibited mainly antiproliferative action. This effect was dependent on concentration of 2$\mathrm{ME}$ and type of cells (ER positive or negative). 2-ME acted only as an antiproliferative (but not mitogenic) factor on ER-negative cells (14). Additionally, reports about mechanisms of methoxyestradiol action are ambiguous. According to studies of Spicer et al. (21), 2ME stimulated production of $\mathrm{LH}$ and acted by binding to oestrogen receptor, but this affinity compared to oestradiol, was very low, in both: $\alpha$ and $\beta$ form. In contrast, Shang et al. (19) noted that 2-ME could act by different receptor or by other undiscovered way. It is important to emphasise that it is difficult to confront entirely the results of our study with the literature data, because to our knowledge, no other reports on the effect of 2-ME on gonadotropin secretion by porcine pituitary cells have appeared so far.

Basini et al. (3) found that 2-ME inhibits $\mathrm{O}_{2}{ }^{-}$ generation but stimulates the activity of superoxide dismutase (SOD) in porcine granulosa cells. These data are incompatible with the findings of Das et al. (7) who showed that 2-ME causes death of tumour cells by the increase in superoxide anion radical generation. Additionally, Huang et al. (10) reported that 2-ME increases superoxide production by inhibiting the activity of cellular superoxide dismutases. In our experiment, the correlation between 2-ME and $\mathrm{O}_{2}^{-}$level was also positive, whereas MDA level did not change significantly under the influence of various concentrations of methoxyestradiol. Supposedly, the observed augmented level of $\mathrm{O}_{2}^{-}$did not cause a marked oxidative stress and lipid peroxidation in porcine pituitary cells due to relatively short time $(2-72 \mathrm{~h})$ of exposition to 2-ME.

The obtained results suggest that methoxyestradiol used in high concentration for the treatment of sows may decrease LH secretion and as a consequence cause some reproductive disorders, both during follicular phase of the oestrous cycle (e.g. delay or inhibition of ovulation resulting in ovarian cyst development) and pregnancy (abortion due to premature regression of gestational corpus luteum). Simultaneously, it did not exert the suppressive effect on FSH secretion and presumably, should not cause FSHmediated disturbances in ovarian follicle selection and early follicular development. However, the further studies are necessary to find the reason of difference in $\mathrm{FSH}$ and LH secretion under the influence of high concentrations of 2-ME.

\section{References}

1. Banerjeei S.K., Zoubine M.N., Sarkar D.K., Weston A.P., Shah J.H., Campbell D.R.: 2-Methoxyestradiol blocks estrogen-induced rat pituitary tumor growth and tumor angiogenesis: possible role of vascular endothelial growth factor. Anticancer Res 2000, 20, 2641-2645.

2. Basini G., Bussolati S., Santini S.E., Bianchi F., Careri M., Mangia A., Musci M., Grasselli F.: Antiangiogenesis in swine ovarian follicle: A potential role for 2methoxyestradiol. Steroids 2007, 72, 660-665.
3. Basini G., Santini S.E., Grasselli F.: 2-Methoxyestradiol inhibits superoxide anion generation while it enhances superoxide dismutase activity in swine granulosa cells. Ann N Y Acad Sci 2006, 1091, 34-40.

4. Bianchi F., Mattarozzi M., Careri M., Mangia A., Musci M., Grasselli F., Bussolati S., Basini G.: An SPME-GCMS method using an octadecyl silica fibre for the determination of the potential angiogenesis modulators $17-\beta$ estradiol and 2-methoxyestardiol in culture media. Anal Bioanal Chem 2010, 396, 2639-2645.

5. Bogacka I., Siawrys G., Okrasa S., Kamiński T., Przała J.: The influence of $\mathrm{GnRH}$, oxytocin and vasoactive intestinal peptide on the secretion of $\beta$-endorphin and production of cAMP and cGMP by porcine pituitary cells in vitro. Anim Reprod Sci 2002, 69, 125-137.

6. Bourghardt J., Bergstrom G., Krettek A., Sjoberg S., Boren J., Tivesten A.: The endogenous estradiol metabolite 2-methoxyestradiol reduces atherosclerotic lesion formation in female apolipoprotein $\mathrm{E}$ - deficient mice. Endocrinology 2007, 148, 4128-4132.

7. Das U.N.: A radical approach to cancer. Med Sci Monit 2002, 8, 79-92.

8. Fenoy F.J., Hernandez M.E., Hernandez M., Quesada T., Salom M.G.: Acute effects of 2-methoxyestradiol on endothelial aortic NO release in male and ovariectomized female rats. Nitric Oxide 2010, 23, 12-19.

9. Hagen T., D'Amico G., Quintero M., Palacios-Callender M., Hollis V., Lam F., Moncada S.: Inhibition of mitochondrial respiration by anticancer agent 2-ME. Biochem Biophys Res Commun 2004, 322, 923-929.

10. Huang P., Feng L., Oldham E.A., Keating M.J., Plunkett W.: Superoxide dismutase as a target for the selective killing of cancer cells. Nature 2000, 407, 390-395.

11. Kosior-Korzecka U., Bobowiec R.: Effect of leptin, insulin and IGF-I on GnRH-induced LH secretion from porcine pituitary cells in vitro. Bull Vet Inst Pulawy 2007, 51, 439-443.

12. Kosior-Korzecka U., Bobowiec R.: Leptin effect on nitric oxide and GnRH-induced FSH secretion from ovine pituitary cells in vitro. J Physiol Pharmacol 2006, 57, 637-647.

13. LaVallee T.M., Zhan X.H., Herbstritt Ch.J., Kough E.C., Green S.J., Pribluda V.S.: 2-Methoxyestradiol inhibits proliferation and induces apoptosis independently of estrogen receptors $\alpha$ and $\beta$. Cancer Res 2002, 62, 36913697.

14. Liu Z.J., Zhu B.T.: Concentration-dependent mitogenic and antiproliferative actions of 2-methoxyestradiol in estrogen receptor-positive human breast cancer cells. J Steroid Biochem 2004, 88, 265-275.

15. Mueck A.O., Seeger H.: 2-Methoxyestradiol-biology and mechanism of action. Steroids 2010, 75, 625-631.

16. Newman S.P., Foster P.A., Ho Y.T., Day J.M., Raobaikady B., Kasprzyk P.G., Leese M.P., Potter B.V.L., Reed M.J., Purohit A.: The therapeutic potential of a series of orally bioavailable antiangiogenic microtubule disruptors as therapy for hormoneindependent prostate and breast cancers. $\mathrm{Br} \mathrm{J}$ Cancer 2007, 97, 1673-1682.

17. Pribluda V.S., Gubish E.R., LaVellee T.M., Treston A., Swartz G.M., Green S.J.: 2-Methoxyestradiol: an endogenous antiangiogenic and antiproliferative drug candidate. Cancer Metastasis Rev 2000, 19, 173-179.

18. Ricker J.L., Chen Z., Yang X.P., Pribluda V.S., Swartz G.M., Van Waes C.: 2-Methoxyestradiol inhibits hypoxia-inducible factor $1 \alpha$, tumor growth, and angiogenesis and augments paclitaxel efficacy in head 
and neck squamous cell carcinoma. Clin Cancer Res 2004, 10, 8665-8673.

19. Shang W., Konidari I., Schomberg D.W.: 2Methoxyestradiol, an endogenous estradiol metabolite, differentially inhibits granulosa and endothelial cell mitosis: a potential follicular antiangiogenic regulator. Biol Reprod 2001, 65, 622-627.

20. Schumacher G., Neuhaus P.: The physiological estrogen metabolite 2-methoxyestradiol reduces tumor growth and induces apoptosis in human solid tumors. J Cancer Res Clin Oncol 2001, 127, 405-410.
21. Spicer L.J., Walega M.A., Hammond J.M.: Metabolism of $\left[{ }^{3} \mathrm{H}\right] 2$-hydroxyestradiol by cultured porcine granulosa cells: Evidence for the presence of a catechol-Omethyltransferase pathway and a direct stimulatory effect of 2-methoxyestradiol on progesterone production. Biol Reprod 1987, 36, 562-571.

22. Zacharia L.C., Jackson E.K., Gillespie D.G., Dubey R. $\mathrm{K}$.: Increased 2-methoxyestradiol production in human coronary versus aortic vascular cells. Hypertension 2001, 37, 658-662. 